\title{
Why to publish on mathematics education so as to be useful? Educational Studies in Mathematics and its founder Hans Freudenthal
}

\author{
Danny Beckers ${ }^{1}$ (D) \\ Published online: 5 February 2019 \\ (C) The Author(s) 2019
}

\begin{abstract}
In 1968, Hans Freudenthal launched the journal Educational Studies in Mathematics. This paper describes the events leading to the foundation of this journal. It turns out that his wife, Suus Freudenthal, deserves more credit for her husband's interest and achievements in mathematics education. The couple was interested in education from a social democratic perspective. The events leading to the foundation of the journal show that lack of success for Dutch national educational reforms, combined with problems noted by his colleagues abroad on their respective reforms, triggered Hans Freudenthal to embark on this enterprise, and contributed to its success.
\end{abstract}

Keywords History of mathematics education $\cdot$ Journal $\cdot$ History of mathematics

The title of this article is, of course, a pun referring to the first article appearing in the very first issue of this journal, currently about 50 years old. In that first issue of Educational Studies in Mathematics, Hans Freudenthal published the notes of his opening address of the 1967 ICMI colloquium in Utrecht: Why to teach mathematics so as to be useful. The theme of the colloquium was "How to ..." et cetera, but Freudenthal, careful not to overstate his case and at the time just entering the scene of mathematics education (Beckers, 2016b), made a modest contribution, by sketching out the reasons behind the theme of the colloquium. This article will sketch out the reasons behind the founding of the journal: Why was the publication of Educational Studies in Mathematics considered necessary at the time? (cf Hanna \& Sidoldi, 2002)

The rise of Educational Studies in Mathematics comprises two stories, unfolding simultaneously. First, it is the story of mathematicians, united in an International Mathematical Union, but at the same time politically divided, most notably on the point of mathematics education. Second, it is the story of mathematics educators, who were desperately looking for ways to

Danny Beckers

d.j.beckers@vu.nl

1 Faculteit Exacte Wetenschappen, Vrije Universiteit Amsterdam, De Boelelaan 1081, 1081

HVAmsterdam, The Netherlands 
improve mathematics education in their respective countries. They, too, were divided with respect to how to improve education. Both stories revolve around the person of Hans Freudenthal, who decided in 1967 the time had come to strengthen the position of the mathematics educators.

This combined story will be told by outlining the story of the mathematicians, then telling the tale of education, and finally continuing the story on the personal level of Hans and Suus Freudenthal. Both were anxious to improve the position of teachers, and in the 1960s both were convinced that teachers were the key to improving education. After that, we can better understand why the founding of the journal was essential to Freudenthal.

\section{International Mathematical Union}

Around 1900, mathematics was becoming an international business. Several national mathematical societies, mostly founded in the second half of the nineteenth century, started exchanging journals. International review journals were founded. From that form of communication sprang the idea of international conferences, the first taking place in Zürich, in 1897. It was during one of these international conferences, at first mostly used as a way to boost the national ego (Alberts \& Beckers, 2010; Rice \& Wilson, 2003), that the idea of the Union Mathématique Internationale (UMI) arose. Founded in 1920 during an international conference in Strasbourg, the Union was discontinued during the growing political unrest and economically harsh times of the early 1930 s.

In 1950, the International Mathematical Union (IMU) was founded. It has been suggested that the union was in a coma from 1933 until 1950 (Letho, 1998). Did this organization really continue the work of the pre-war UMI? In a sense, it did, but in many respects, the IMU was a completely new organization. This may be illustrated by its language, which had become English, but also by its political ties. The IMU conference, organized in 1954 in Amsterdam, for example, was politically charged: Mathematicians were not only rebuilding international relationships with their colleagues, they were also offering advice to their respective governments. In the Netherlands, mathematicians were organized within the new Mathematisch Centrum (Mathematical Centre, founded in 1946), which had the explicit aim and ambition of helping to rebuild the country, with the assistance of mathematical knowledge. The new status and new expectations of mathematical research after the war were illustrated by the ease of receiving funding, and by the fact that the Dutch queen would receive a delegation from the IMU for afternoon tea (Alberts, 1998).

Meanwhile, mathematics, in the post war representation of the field to the outside world, had grown into a more abstract field. It was the French group Bourbaki that set out to redefine what mathematics was about, by rewriting the entire mathematical corpus on the basis of set theory. Although within the field of mathematics there was no unanimity on the Bourbakist view of mathematics, this was the way mathematics was presented by the IMU. Although a minority view, Bourbaki was presented attractively as the essence of mathematics: The more abstract mathematics was, the less one had to learn, the less one would burden the minds of pupils, generating deeper understanding and leaving more time to focus on applications (Phillips, 2014). Within mathematics education, however, how to teach was also a matter of tradition and political structure, thereby making it even more difficult to achieve consensus on how to teach and to what end. Government officials, quite willing to talk about funding mathematical research, or assisting to acquire funding, might baulk if an educational agenda 
was suspected (Phillips, 2015; Reese, 2013; also note the example of L. N. H. Bunt below). This difficulty made the IMU very cautious in developing its policy regarding mathematics education.

\section{Mathematics education}

In general, mathematicians regarded mathematics education, though not as their responsibility, as a field of interest. Most Western countries had a form of obligatory mathematics in the curricula of primary and secondary schools. Typically, mathematics teachers would have studied mathematics (although not necessarily acquiring a doctorate) and would draw support from practicing mathematicians. They rarely received more than moral support.

Unlike mathematics educators, who were quite satisfied with the position their subject had in school curricula, more general educators did not appear as pleased. It was recognized that the educational system in most countries served to reproduce existing social stratifications. Whereas this was considered as the positive idea behind the school system by some (cf Beckers, 2017), socialists, including many psychologists, took an opposing stance. In the 1950s and 1960s, it would more generally become a non-desirable quality of the school system, as voiced, for example, by UNESCO official Philip Coombs (1968). But also before World War II, some academics and teachers pleaded for more child-centered education - they thought, for example, that education was putting far too much emphasis on memorizing and too little on creating responsible citizens. Various groups among them took various stances towards mathematics education and the schooling system, but the New Educational Fellowship (NEF) should be mentioned here explicitly. Not because it was politically successful: although it was truly international, before 1945, the NEF was ineffective in reaching beyond its rather confined circle of upper middle class left wing idealists. Nor because its ideas were new: the NEF attempted to popularize ideas by Montessori, Steiner, Freinet and others. The NEF, in the 1920s, did voice the idea that pupils had to be approached as individuals and that teaching was more effective if it was somehow adjusted to the needs of the individual pupil (Brehony, 2004). It would use the political momentum after World War II to its advantage. Moreover, the $\mathrm{NEF}$, or at least its Dutch branch, would play a small part in the founding of Educational Studies in Mathematics.

The journal l'Enseignement Mathématique (Teaching Mathematics) was founded in 1899. It featured papers on mathematics education, as well as on mathematics - it published mainly in the lingua franca of the time: French. The Commission Internationale de l'Éducation Mathématique (CIEM) later adopted it as its formal journal. This commission was founded in 1908, at the international conference of mathematicians in Rome. It focused on gathering information on curricula (what was taught) and didactics (the way it was taught) in its, mostly Western, member countries. Although individual members certainly used the journal as political leverage within their own countries, to reach curriculum changes, the aim of the journal was certainly not political. l'Enseignement Mathématique aspired to publish papers by neutral mathematicians who gathered only value-free information. Didactics (European version of domain-specific pedagogy) was seen as belonging to the subject being taught; that is, it was considered to be as universal as was mathematics (Furinghetti, 2003, 2007). 
From 1920 onwards, CIEM was an official commission of the (interbellum) UMI. This may seem strange, but at the time it was only natural: members of the CIEM were mathematicians, not mathematics educators and certainly not mathematics teachers. CIEM had been organized from within the international mathematics conferences, from which the union also originated. It fit the notion of mathematicians supporting the work of "their teachers" (Beckers, 2016a). As with the IMU, both the NEF and CIEM were discontinued in the political turbulence of the 1930s.

After the war, the idea that all citizens should benefit equally from education-either from political motives or from economical ones - became mainstream. Moreover, the NEF educational ideal became politically much more influential: It became politically mainstream to claim that school had to contribute to students' citizenship, and that individual needs had to be taken into account. In many Western European countries, NEF ideals began to play a role in educational policy (Clews, 2009). Most notably, in the Netherlands, both the queen and the minister of education were very much in favor of the experimental school, ran by the NEF representatives (Hooghiemstra, 2013).

Mathematics educators were also considering how mathematics education could be improved to reach more students; they held that mathematics could be better introduced, or perhaps mathematics teachers should change their goals. Some believed that the influence of the teacher should be reduced or replaced by the more objective measurements of standardized tests. The movement towards test psychology (or psychometry) was an international one, but was particularly successful in the Netherlands, where the creation of a central testing bureau had been seriously considered since 1965, and where such a bureau was established in 1968 (Busato, 2014). The alternative view, which was popular among Western European mathematics teachers, was that teacher training facilities should be greatly improved, to educate more, morally sound, teachers, who would be optimally equipped to recognize and address the pupils' individual needs.

In 1954, ICMI was reborn from the ashes of CIEM (Howson, 1984). But ICMI was not alone anymore, and it was conscious of this fact. From France originated the rather successful group - in terms of number of participants and study activities - CIEAEM (Commission Internationale de l'Étude et Amélioration de l'Éducation Mathématique), active in Europe since the late 1940s (Félix, 1985). In the USA, starting in the early 1950s, the Illinois project directed by Max Beberman (1925-1971) was experimenting with new concepts of learning, most notably discovery learning. Both groups engaged in changing existing teaching practices, cooperated with psychologists, and were also politically active: trying to secure funding and attempting to convince schools or teachers to participate in projects. Even where they diverged on their educational philosophy, they certainly knew what mathematics was about: very much in line with their colleagues within mathematics, they had modern mathematics in mind, the so-called "New Math," that emphasized structure and the unity of mathematics. Mathematics came in only one flavor: Bourbaki (Phillips, 2014). Nevertheless, mathematics education came in many flavors and not every pupil had to reach the ultimate goal. Successes in mathematics education depended on a successful teacher. The concept of didactics changed: the idea that an ideal way of teaching depended only on the subject taught, was abandoned, in favor of attention for the individual learning process (Furinghetti, 2008).

Moreover, the new ICMI was a commission of the IMU, with no independent means. The board of the IMU made it very clear from the start that ICMI would not have its own budget. They were to be a commission of the IMU, which could apply for funding from the board on a project basis. The commission could not set out its own policy (Furinghetti, 2008). In practice, 
ICMI did not take part in any of the initiatives in mathematics education during the 1950s and 1960s. This was the IMU policy at the time: this modus operandi helped to keep out of political difficulties, which was essential for the IMU board. The official ICMI journal, l'Enseignement Mathématique, complied with that policy, by publishing mainly on mathematical subjects: Of the 282 papers published between 1955 and 1969, only 51 may be described as being about mathematics education. Most of these were written by ICMI officials or treated ICMI inquiries (Furinghetti, 2009). Needless to say, that ICMI inquiries were to restrict themselves to observations of existing practices, not favoring any particular approach.

Educators increasingly felt the need to change education, and they were becoming more anxious to bring about this change. After the launch of Sputnik (1957), Edward Begle (19141978) used the political momentum in the USA to found the Yale-based School Mathematics Study Group, which rapidly expanded its working area (Phillips, 2015). In Europe, many countries started reform committees to investigate the possibilities and limitations of their respective mathematics curricula (Beckers, 2016a). In the Netherlands, it was the Utrecht mathematics teacher trainer Lucas Bunt (1905-1984) who sparked more research on "the perfect" way of teaching mathematics, and "the perfect" curriculum. As the most important (or rather, the least controversial) Dutch author and speaker on mathematics education, he had been sent to the 1959 conference in Royaumont and had returned enthusiastically. He had come into contact with several people from CIEAEM and had great confidence in their Bourbaki-style ideas. To the Ministry of Education he proposed that he would lead a research institute and asked for funding. Unfortunately for Bunt, within the corps of inspectors, a number of people opposed him. So, while the government did decide to fund a project, it was unclear on whom to give it to. Therefore, the project was assigned to a broad commission, in effect taking it away from Bunt (Archive Ministry of Education, inv.nr. 99, letters dating January 12, 16 and 24; February 2, 20, 28, 1961).

This is how Hans Freudenthal (1905-1990) was drawn into this history: He was one of the people elected to this Commissie Modernisering Leerplan Wiskunde (CMLW, Commission on Modernizing the Mathematics Curriculum). This commission-whose annual budget soon exceeded the total budget Bunt had requested in his original plans - focused on defining a new curriculum, framed in Bourbaki-style mathematics, incorporating modern subjects in mathematics (such as discrete mathematics and numerical mathematics), and organizing teacher training in these subjects, so teachers would be ready to teach them. Freudenthal was at first little more than a front man-he was abroad, teaching at Yale, during the first year of the commission - but with the passing years, his interest and involvement in the subject grew. He started to attend the commission meetings from late 1965 onwards, and became actively involved (Beckers, 2016b).

\section{Freudenthal and Freudenthal}

Born and educated in Germany, Hans Freudenthal was an excellent research mathematician in one of the most abstract fields in early twentieth century mathematics: topology. In the 1920s, he moved to the Netherlands and married Susan Lutter (1908-1986), or Suus, as she was called. Suus was interested in pedagogy and although as Susan Freudenthal, she was no longer supposed to pursue her own career, she devoted much of her time to the Dutch branch of the NEF: from 1950 onwards she edited the journal published by the Dutch NEF branch, organized conferences and supported the development of teaching materials for primary 
schools. Moreover, she was connected to the founding of the first secondary school based on Montessori principles in the Netherlands, and ensured her husband served on the board of that school. In the early 1960s, she learned of Jenaplan education. The Jenaplan ideals offered a rather eclectic approach to education: Aiming to bring together the needs of the individual pupil with the needs and possibilities of the local community, Jenaplan schools expected the teacher to be very reflective and continually aware of the needs of individual pupils and the group, on the level of the pedagogical climate and the content of the learning process. These ideas attracted Susan Freudenthal very much, and she would devote her best years supporting the foundation and development of Jenaplan education in the Netherlands and abroad. She was celebrated by pedagogues, both nationally and internationally: She followed her husband on his travels abroad, always seeking out interesting places and people to further the cause of Jenaplan education. She was in touch with many officials, among them the Minister of Education, and was at ease in picking up the phone and arranging a meeting, in her rather blunt but effective way. In 1985, she was awarded an honorary doctorate for her work at the University of Siegen. For years, Susan was the main link between Hans Freudenthal and the field of education. Her connections and voluntary work shaped his ideas about education, and made him an obvious candidate for board functions related to educational matters. Hans regarded these board functions as his way of supporting mathematics education, without interfering with its content (Beckers, 2016a).

Both Suus and Hans regarded education as the key to rebuilding the country after the war. It was quite clear that a lot of intellectual potential was being wasted, and this was considered both socially unacceptable and economically wasteful. This was recognized as a worldwide problem, and during the violent student protests of the late 1960s even became connected to the word "crisis" (Coombs, 1968). Suus and Hans refrained from using such strong words, their general feeling being more positively inclined, thinking about what could be and how things should be improved. These general ideas, which existed among intellectuals, simply serve to underline the self-evidence with which the Freudenthal couple invested their time in the subject: As members of the scientific elite in the post war decades, it felt to them as their obligation.

Suus had the most elaborate thoughts on the subject. After all, "improving education" had been a key issue within the NEF community, even before the war. Therefore, from the 1950 onwards, with the Dutch organization of the NEF, Suus advocated improvements in the education of primary school teachers. It meant that teachers had to be aware of what was going on within society and in their small sub-community, and to adapt their teaching to the individual needs of pupils, thus helping them to become responsible citizens. From the 1960s onwards, she organized continuous education for teachers within the Jenaplan foundation with the very same goal. Hans was more modest in his contributions, but through his board functions and his membership of the student organization that advocated cheap student loans and grants for poor students, he clearly showed that he cared. In 1965, when he started to show an interest in Dutch secondary education, his key ideas were very much in line with what Suus advocated: strengthening the position of teachers through continuous education (Beckers, 2016b).

There was another way of addressing the problem of education. Psychometricians held that the key problem was not the education of teachers. Using statistics, they had deduced that the teacher usually was the problem: Teachers, either consciously or subconsciously, favored pupils from their own social standing, and thereby middle and upper class children were bound to gain the most profit from education. Their solution was to offer standardized tests, instead of having teachers assess the progress of pupils. In the Netherlands, this direction was 
favored by Adriaan de Groot (1914-2006), who advocated the establishment of a central testing agency that would test all pupils on basic skills acquired during education. In 1965, De Groot was a rising star within Dutch education; in 1968, his bureau was formally established and started running tests - first only in primary education, but from the 1970s also in secondary education (Busato, 2014). Suus and Hans were opposed to these developments. Suus feared that the whole of society and mankind would become subject to measurable statistics. Hans was afraid that students would only learn how to take tests. Both were convinced that tests, unlike the assessment by a well-trained teacher, would not improve education. It was clear to both of them that the two systems of improving education could not productively co-exist.

Both Freudenthals regarded education as an international affair. Suus evidently did so from her NEF background. During her travels in the USA in 1960-1961, while her husband was teaching at Yale, she noted how different the US school system was (Freudenthal-Lutter Archive, inv.nr 10). Most notably, she must have recognized the influence of test psychology, which was trusted far more than it was in Europe (Reese, 2013). Hans must have noticed that the US National Council of Teachers of Mathematics (NCTM) was much more in favor of test psychology. He never established contacts with mathematics educators in the USA, but his international mathematics contacts did earn him a place in ICMI in 1963. From 1966 onwards, Hans was involved in an attempt, orchestrated by NUFFIC (Dutch academics united to further education in developing countries), to establish an institute to further teacher training and mathematics education in developing countries. Ultimately, the idea was abandoned in 1969 (Freudenthal Archive, inv.nr. 1832). Given his international experience and orientation and the educational input from his wife, it thus did not come out of the blue that Hans Freudenthal was elected president of ICMI in 1967.

In 1967, this was the Freudenthal's situation. Hans was freshly elected as the president of ICMI, which was politically paralyzed. Furthermore, he was becoming active within the CMLW, and noticed how, there as well, political decision-making was sluggish at best. At the same time, he noticed that the reach of test psychology was growing within the Netherlands. Suus was the first to note that the, in her view, crippling effects of the central testing agency were soon to become practice. Hans was aware of what was going on in other countries, most notably in the USA, and knew that the only way to counter the rise of test psychology in education was a serious and well-researched alternative from the side of didactics. Research into how to teach mathematics was therefore imperative, and it had a natural connection to the curriculum reforms taking place. On October 26, 1967, Freudenthal therefore actively supported the (second!) CMLW effort to establish a research institute on the didactics of mathematics (Archive Ministry of Education, inv.nr. 99). The failure of this attempt made him focus all the more on the next best thing: a research journal.

\section{Educational Studies in Mathematics}

In Hans Freudenthal's view, doing educational studies in mathematics, working seriously on finding better ways of teaching mathematics, was the job of outstanding mathematics teachers. He knew several of these mathematics teachers, and supported them as needed. Freudenthal recognized additional opportunities for involvement when he visited the ICMI colloquium in 1964 in Utrecht. At least, that is what he himself thought was the first incentive. During that colloquium participants recognized that there was no international journal that would publish 
on mathematics education research (Freudenthal Archive, inv.nr. 1785). This, of course, was a diplomatic way of stating that l'Enseignement Mathématique, notably the official ICMI journal, was no longer publishing papers on mathematics education.

As a result, Freudenthal started gathering support for a new journal in 1965. He secured financial backing from the Reidel publishing company and began gathering a group of supporters. However, it took a few more years before Freudenthal really came into action.

In 1967, Freudenthal was elected president of ICMI. In January, he had organized a UNESCO-sponsored meeting about mathematics education in Lausanne between mathematicians and physicists, in an attempt to reconcile the diverging needs of teachers in both fields regarding mathematics education. One outcome was that applying mathematics was difficult to learn: It was neither straightforward to apply a mathematical theorem, nor did it occur to students naturally. Moreover, it was not a problem that was addressed in educational studies. Freudenthal, who had expressed his regret about the content of the official ICMI journal and who was backed up by his friend André Révuz (Howson, 1984; Nabonnand, 2003; Gispert, 2003), must have recognized it as a perfect opportunity for launching the journal he had in mind. Resourceful as always, he asked the Dutch government and several Dutch universities to sponsor a meeting at Utrecht University, presenting it as an ICMI activity (Freudenthal Archive, inv.nr. 1833), and immediately invited speakers to write their contribution to the event as a contribution to the new journal. The ICMI board was confused but went along. The IMU board was shocked when they found out afterwards: Freudenthal had moved ICMI into a position they had always feared. The financial and political autonomy of ICMI from IMU was at stake: The separation, since 1969, of the conferences on mathematics and mathematics education was one of the results (Furinghetti, 2008).

Among the first people Freudenthal invited were those heading mathematics curriculum revision programs in their respective countries: Max Beberman (Illinois, US), who declined, Emma Castelnuovo (Italy), Lucienne Félix (France), Anna Krygovska (Poland), Willy Servais (Belgium), Bryan Thwaites (UK) and André Révuz (France), all of whom accepted. Also, among the first to accept was Alexander Wittenberg, from New York, who emphasized that the new journal should not become a mathematics journal - thereby not too subtly hinting at what he resented in l'Enseignement Mathématique. As if he had read Freudenthal's mind! Most potential editorial board members were approached only in 1967, when the first issue was almost ready. Only two declined, and Wittenberg died before he could take up his place on the editorial board (Freudenthal Archive, inv.nr. 1785). Freudenthal was careful to approach people he knew were not in favor of test psychology. Almost all of those he had written about his plans in 1965 ended up on the editorial board in 1968, which suggests that this was a wellcoordinated action from the beginning.

One of the people to accept in 1967 was professor P. J. Hilton, from Cornell University. When Freudenthal found out in August 1967 that Hilton was planning to start a journal on mathematics education, he immediately wrote him a letter, suggesting that Hilton could join him, since his first issue was almost ready. Hilton reacted positively, stating on September 22 that he had, indeed, been working on founding a journal, together with his colleagues W. T. Martin (MIT), E. G. Begle (Stanford), G. Choquet (France), and E. B. Dynkin (Cornell). Freudenthal persuaded them to join. In a letter dated November 1, 1967, Hilton suggested the journal title. In the same letter, Hilton asked Freudenthal to postpone his journal, since he had just learned that some people in Chicago were also planning to launch a journal. Freudenthal knew that his journal would not be out before May of the following year, but pressed on, despite expressing reservation: "Nevertheless I must say if I had known about the Chicago 
projects, I would not have started. I did it because no other seemed to do. It is with reluctance that at my age I take new charges on my shoulders. However, now I cannot withdraw," he diplomatically wrote to Hilton, suggesting that the first issue was already there (Freudenthal Archive, inv.nr. 1786). Freudenthal was probably aware that the Chicago group Hilton was referring to was the National Council of Teachers of Mathematics, which was well on its way to launch the Journal for Research in Mathematics Education. The journal did indeed launch in 1970, but this group focused more on empirical analysis and was positively inclined towards test psychology (Johnson, 1970), which Freudenthal did not favor.

His publisher was impressed with Freudenthal's work: although there was no journal title, and no fixed idea about the frequency or number of pages of the journal, Freudenthal was already receiving papers and editing them (Freudenthal Archive, inv.nr. 1787). Meanwhile, the first problems emerged. Révuz had already expressed his concern about the ICMI journal l'Enseignement Mathématique. Indeed, the IMU board was not at all amused with its rogue official pursuing non-approved projects, and Freudenthal's claim that the editorial board would be installed by ICMI was a typical bluff. It came to a clash between the IMU board and the ICMI (most notably Freudenthal), which was resolved by a compromise: The editoral board would be installed by ICMI, but the journal would not become an official ICMI journal.

Freudenthal's editorial policy of keeping all the decisions about papers to be published to himself secured the direction of Educational Studies in Mathematics: It was to be a journal that should appeal to people who wanted to improve mathematics education by means of research into "the perfect" didactical approach - he kept his faith that this existed, but he left it to the authors what the end results of such education should be. The early authors were not only professional researchers, but also, if only a few, teachers, who were actively pursuing new ways of mathematics education (Freudenthal Archive, inv.nrs. 1790, 1801-1806).

\section{Concluding remarks}

In 1967, Hans Freudenthal (1905-1990) launched the journal Educational Studies in Mathematics, with its first issues appearing in 1968. At the time, this was an act of rebellion, selfconsciously plotted by Freudenthal, who was unhappy with the speed of change within mathematics teaching in secondary education. Although his dissatisfaction originated from a local, Dutch context, he recognized that neither mathematicians nor mathematics educators within countries could support change by themselves: They needed the numbers and political backing of an international organization to actually realize change. Intermingling national and international funding and interests turned out to be an advantageous policy to get his waymany others with national interests were eager to help him.

The board of IMU was not going to support him: They held to a traditional view of mathematicians supporting secondary education. They put their trust in the course set by the editorial board of l'Enseignement Mathématique, which had been turned into a journal that showed teachers and teacher educators what mathematics was about. This was the opposite of what Freudenthal thought should happen - an opinion that he shared with many in the field of mathematics education, and which was completely in line with his post-war optimism on the educational field, an optimism he shared with his wife.

Publishing on mathematics education so as to be useful was neither self-evident, nor easily established. Mathematicians within the IMU firmly believed that every country should do that for itself and that it was the IMU's job to show teachers and teacher trainers what mathematics 
was - a conviction rooted in the unity of science movement. Freudenthal recognized the opportunity and seized it, financially supported by funding from organizations he was familiar with. Moreover, through his editorial board, he felt morally supported by the important organizations within Europe and his (selected) US contacts.

Freudenthal risked losing the backing of the IMU, but he gained momentum in the continental European countries and from UNESCO, where most of his financial aid came from. Did it work, one might ask? Did Educational Studies in Mathematics really benefit mathematics education? Although I dare not answer that question, it is known that Freudenthal himself was not very happy with the overall quality of the papers in his journal, and he did not like the direction mathematics educators were heading in the late seventies - although he never ceased to support them. Politically, the founding of the journal helped to professionalize research in mathematics education. Both the French IREM (1968) and the Dutch IOWO (1970) benefited in their own ways from the existence of the journal; similarly, the German GDM (1975) profited from the international attention for mathematics education. This is not to say that these organizations were the immediate result of the founding of Educational Studies in Mathematics, but the journal did offer them an international publication medium with an international body-although not directly - that illustrated their relevance, and offered (increased) political leverage. In 1970, the world looked bright to Hans Freudenthal: He had established an international research journal, he had become the director of an institute that was going to do research in how to teach mathematics, and it seemed as if the didactical movement in education could actually reduce the influence of psychometrics. Before the end of the decade, the situation looked far more gloomy. But the research journal was still thriving (as it is today!), and the relationship between IMU and ICMI had definitely improved.

Open Access This article is distributed under the terms of the Creative Commons Attribution 4.0 International License (http://creativecommons.org/licenses/by/4.0/), which permits unrestricted use, distribution, and reproduction in any medium, provided you give appropriate credit to the original author(s) and the source, provide a link to the Creative Commons license, and indicate if changes were made.

Publisher's note Springer Nature remains neutral with regard to jurisdictional claims in published maps and institutional affiliations.

\section{References}

Alberts, G. (1998). Jaren van berekening. Toepassingsgerichte initiatieven in de Nederlandse wiskundebeoefening 1945-1960 [Calculating years. Applied initiatives in Dutch mathematics]. Amsterdam: AUP.

Alberts, G., \& Beckers, D. (2010). Wiskunstige Verlustiging. De tijdschriften die het genootschap wel en niet uitgaf, 1770-2000 [mathematical joys. The journals that the Dutch mathematical society did and did not publish]. Nieuw Archief voor Wiskunde (V), 11, 20-26.

Archive Hans Freudenthal, archive number 615, Archival service "Noord-Hollands Archief", North Holland State Archive, Haarlem, the Netherlands.

Archive Susan Freudenthal-Lutter, archive number 767, Archival service "Noord-Hollands Archief", North Holland State Archive, Haarlem, the Netherlands.

Beckers, D. (2016a). Marvelous mathematics. How mathematicians wanted to improve the quality of life in Western Europe, 1945-1975. DVT. Dějiny Věd a Techniky, 49, 227-248.

Beckers, D. (2016b). Wiskundige voor een betere wereld. Hans Freudenthal (1905-1990) als onderwijskundige [mathematician for a better world. Hans Freudenthal (1905-1990) as educational scientist]. In V. Busato, M. 
van Essen \& W. Koops (Eds.), Zeven grondleggers van de onderwijskunde [Seven founding fathers of educational science] (pp. 113-158). Amsterdam, the Netherlands: Bert Bakker.

Beckers, D. (2017). HBS: van modern instituut naar fossiel in 100 jaar [HBS: from modern institute to fossil in 100 years]. Studium, 10, 149-159.

Brehony, K. (2004). A new education for a new era: The contribution of the conferences of the NEF to the disciplinary field of education, 1921-1938. Peadagogica Historica, 40, 733-755.

Busato, V. (2014). A. D. de Groot (1914-2006): meester in de psychologie [A. D. de Groot (1914-2006): master in psychology]. In V. Busato, M. van Essen, \& W. Koops (Eds.), Van fenomenologie naar empirischanalytische psychologie [From phenomenology to empiric-analytical psychology] (pp. 249-314). Amsterdam, the Netherlands: Bert Bakker.

Clews, C. J. (2009). The NEF and the reconstruction of education 1945-1966. PhD Thesis University College London.

Coombs, P. H. (1968). The world educational crisis - A systems analysis. New York. London, UK: Oxford University Press.

Félix, L. (1985). Aperçu historique (1950-1984) sur la Commission Internationale pour l'Étude et l'Amélioration de l'Enseignement Mathématiques (CIEAEM) [Historical remarks (1950-1984) on the CIEAEM] (2nd edition). Bordeaux, France: IREM. http://math.unipa.it/ grim/cieaem_files/CIEAEM_ histoire_FLucienne_1985.pdf

Furinghetti, F. (2003). Mathematical instruction in an international perspective: the contribution of the journal l'Enseignement Mathématique. In D. Coray et al. (Eds.), One Hundred years of l'Enseignement Mathématique (pp. 21-46). Geneva, Switzerland.

Furinghetti, F. (2007). Mathematics education and ICMI in the proceedings of the international congresses of mathematicians. Revista Brasileira de História da Matemática Especial, 1, 97-115.

Furinghetti, F. (2008). Mathematics education in the ICMI perspective. International Journal for the History of Mathematics Education, 3, 47-56.

Furinghetti, F. (2009). The evolution of the journal L'Enseignement Mathématique from its initial aims to new trends. In K. Bjarnadóttir et al. (Eds.), Dig where you stand. Proceedings of the conference on on-going research in the history of mathematics education (pp. 31-46). Reykjavik, Iceland: University of Iceland, School of Education.

Gispert, H. (2003). Applications: les mathématiques comme discipline de service dans les années 1950-1960 [Applications: mathematics as a tool during the years 1950-1960]. In D. Coray et al. (Eds.), One Hundred years of l'Enseignement Mathématique (pp. 251-270). Geneva, Switzerland.

Hanna, G., \& Sidoldi, N. (2002). The story of ESM. Educational Studies in Mathematics, 50, 123-156.

Hooghiemstra, D. (2013). De geest in dit huis is liefderijk. Het leven en de werkplaats van Kees Boeke (18841966) [The spirit of this house is full of love. Life and the working place of Kees Boeke (1884-1966)]. Utrecht / Amsterdam / Antwerpen: De Arbeiderspers.

Howson, A. G. (1984). Seventy five years of the international commission on mathematical instruction. Educational Studies in Mathematics, 15, 75-93.

Johnson, D. C. (1970). Editorial comment. Journal for Research in Mathematics Education, 1, 5-6.

Letho, O. (1998). Mathematics without borders. A history of the International Mathematical Union. Berlin, Germany: Springer.

Nabonnand, Ph. (2003). Les débats autour des applications des mathématique. Rapport sur la période 1963-1966 [The debates about applications of mathematics. Report on the years 1963-1966]. In D. Coray et al. (Eds.), One Hundred years of L'Enseignement Mathématique (pp. 229-249). Geneva, Switzerland.

National Archive The Hague, Archive Ministry of Education and Science, department of secondary education, number 2.14.43, archival block O27580.

Phillips, C. J. (2014). In accordance with a "more majestic order". The new math and the nature of mathematics at midcentury. Isis, 105, 540-563.

Phillips, C. J. (2015). The new math. A political history. Chicago, IL: University of Chicago Press.

Reese, W. J. (2013). Testing wars in the public school. A forgotten history. Cambridge, MA: Harvard University Press.

Rice, A., \& Wilson, R. (2003). The rise of British analysis in the early $20^{\text {th }}$ century: The role of G.H. Hardy and the London Mathematical Society. Historia Mathematica, 30, 173-194. 